\title{
Phenotypic and genetic differentiation between native and introduced plant populations
}

\author{
Bossdorf, Oliver ; Auge, Harald ; Lafuma, Lucile ; Rogers, William E ; Siemann, Evan ; Prati, Daniel
}

\begin{abstract}
Plant invasions often involve rapid evolutionary change. Founder effects, hybridization, and adaptation to novel environments cause genetic differentiation between native and introduced populations and may contribute to the success of invaders. An influential idea in this context has been the Evolution of Increased Competitive Ability (EICA) hypothesis. It proposes that after enemy release plants rapidly evolve to be less defended but more competitive, thereby increasing plant vigour in introduced populations. To detect evolutionary change in invaders, comparative studies of native versus introduced populations are needed. Here, we review the current empirical evidence from: (1) comparisons of phenotypic variation in natural populations; 2 comparisons of molecular variation with neutral genetic markers; (3) comparisons of quantitative genetic variation in a common environment; and (4) comparisons of phenotypic plasticity across different environments. Field data suggest that increased vigour and reduced herbivory are common in introduced plant populations. In molecular studies, the genetic diversity of introduced populations was not consistently different from that of native populations. Multiple introductions of invasive plants appear to be the rule rather than the exception. In tests of the EICA hypothesis in a common environment, several found increased growth or decreased resistance in introduced populations. However, few provided a full test of the EICA hypothesis by addressing growth and defence in the same species. Overall, there is reasonable empirical evidence to suggest that genetic differentiation through rapid evolutionary change is important in plant invasions. We discuss conceptual and methodological issues associated with cross-continental comparisons and make recommendations for future research. When testing for EICA, greater emphasis should be put on competitive ability and plant tolerance. Moreover, it is important to address evolutionary change in characteristics other than defence and growth that could play a role in plant invasions
\end{abstract}

DOI: https://doi.org/10.1007/s00442-005-0070-z

Posted at the Zurich Open Repository and Archive, University of Zurich

ZORA URL: https://doi.org/10.5167/uzh-156677

Journal Article

Published Version

Originally published at:

Bossdorf, Oliver; Auge, Harald; Lafuma, Lucile; Rogers, William E; Siemann, Evan; Prati, Daniel (2005). Phenotypic and genetic differentiation between native and introduced plant populations. Oecologia, 144(1):1-11.

DOI: https://doi.org/10.1007/s00442-005-0070-z 


\section{Oliver Bossdorf · Harald Auge $\cdot$ Lucile Lafuma \\ William E. Rogers · Evan Siemann · Daniel Prati \\ Phenotypic and genetic differentiation between native and introduced plant populations}

Received: 20 September 2004 / Accepted: 22 February 2005 / Published online: 11 May 2005

(C) Springer-Verlag 2005

\begin{abstract}
Plant invasions often involve rapid evolutionary change. Founder effects, hybridization, and adaptation to novel environments cause genetic differentiation between native and introduced populations and may contribute to the success of invaders. An influential idea in this context has been the Evolution of Increased Competitive Ability (EICA) hypothesis. It proposes that after enemy release plants rapidly evolve to be less defended but more competitive, thereby increasing plant vigour in introduced populations. To detect evolutionary change in invaders, comparative studies of native versus introduced populations are needed. Here, we review the current empirical evidence from: (1) comparisons of phenotypic variation in natural
\end{abstract}

Communicated by Christian Koerner

O. Bossdorf $(\bowtie) \cdot$ H. Auge $\cdot$ D. Prati

UFZ - Centre for Environmental Research Leipzig-Halle, Department of Community Ecology, Theodor-Lieser-Str. 4, 06120 Halle, Germany

O. Bossdorf

Institut für Umweltwissenschaften, Universität Zürich, Winterthurerstrasse 190, 8057 Zürich, Switzerland

L. Lafuma

ISEM, cc 065, Université de Montpellier II,

Place Eugene Bataillon, 34095 Montpellier, France

W. E. Rogers · E. Siemann

Department of Ecology and Evolutionary Biology,

Rice University, MS 170, 6100 Main Street,

Houston, TX, 77005 USA

Present address: O. Bossdorf

Department of Ecology and Evolution,

State University of New York, 650 Life Sciences Building,

Stony Brook, NY 11794-5245, USA

E-mail: bossdorf@life.bio.sunysb.edu

Tel.: + 1-631-6321669

Fax: + 1-631-6327626

Present address: W. E. Rogers

Department of Rangeland Ecology and Management, Texas A\&M University, 2126 TAMU, College Station, TX 77843, USA populations; (2) comparisons of molecular variation with neutral genetic markers; (3) comparisons of quantitative genetic variation in a common environment; and (4) comparisons of phenotypic plasticity across different environments. Field data suggest that increased vigour and reduced herbivory are common in introduced plant populations. In molecular studies, the genetic diversity of introduced populations was not consistently different from that of native populations. Multiple introductions of invasive plants appear to be the rule rather than the exception. In tests of the EICA hypothesis in a common environment, several found increased growth or decreased resistance in introduced populations. However, few provided a full test of the EICA hypothesis by addressing growth and defence in the same species. Overall, there is reasonable empirical evidence to suggest that genetic differentiation through rapid evolutionary change is important in plant invasions. We discuss conceptual and methodological issues associated with cross-continental comparisons and make recommendations for future research. When testing for EICA, greater emphasis should be put on competitive ability and plant tolerance. Moreover, it is important to address evolutionary change in characteristics other than defence and growth that could play a role in plant invasions.

Keywords Biological invasions - Ecological genetics · Microevolution · Molecular markers · Phenotypic plasticity

\section{Introduction}

As a result of global trade and transport, the number of plant species introduced to novel areas by humans has increased dramatically. Some of these species become very abundant in their introduced range and cause serious environmental and economic problems. They can outcompete native species, and change the structure and functioning of native communities and ecosystems 
(Vitousek et al. 1996; Mack et al. 2000; Levine et al. 2003). Biological invasions are therefore regarded as one of the greatest current threats to global biodiversity (Sala et al. 2000). Moreover, some introduced species cause major economic problems in agriculture and forestry (Perrings et al. 2000; Pimentel et al. 2000). Because of these negative effects, much research has already been carried out on the causes and consequences of biological invasions, and their control (for overviews see e.g. Drake et al. 1989; Williamson 1996; Mack et al. 2000). However, this work has often been of limited success and revealed our insufficient understanding of population dynamics, ecological interactions among species, and the stability of ecosystems (Gilpin 1990; Lodge 1993; Lonsdale 1999; Sakai et al. 2001). While most of the previous research has been purely ecological, invasion biologists have recently begun to focus on another potential explanation for the success of invaders: rapid evolutionary change.

Evolution can be rapid and therefore relevant to ecological studies (Thompson 1998). Invasive species, in particular, might evolve for several reasons: First, there might be evolution by genetic drift and inbreeding in founder populations (Brown and Marshall 1981; Barrett and Husband 1990). Second, inter- or intraspecific hybridization in the introduced range may create novel genotypes (Ellstrand and Schierenbeck 2000). Third, invasions into novel environments often involve drastic changes in selection regimes that may cause adaptive evolutionary change (Mooney and Cleland 2001; Sakai et al. 2001). Many of the species that become invasive do so after a lag time (Kowarik 1995; Williamson 1996), perhaps after such evolutionary adjustments have taken place. Because of the unusual combination of genetic bottlenecks and changing selection regimes, invasive species may in fact provide some of the best model systems for studying rapid evolution in action (Thompson 1998; Reznick and Ghalambor 2001; Hänfling and Kollmann 2002; Lee 2002).

One hypothesis that has been particularly influential in the context of plant invasions is the Evolution of Increased Competitive Ability (EICA) hypothesis by Blossey and Nötzold (1995). Many invasive plants appear to grow more vigorously in their introduced than in their native range (Crawley 1987). This has commonly been attributed to a release from natural enemies (Maron and Vilà 2001; Keane and Crawley 2002). The EICA hypothesis, in contrast, proposes that after enemy release, plants evolved greater vigour. If there is a trade-off between resource allocation to growth and defence, natural selection should favour less defended but more competitive genotypes in the introduced range (Blossey and Nötzold 1995).

Defence and competitive ability are important characteristics of invasive plants, but they are almost certainly not the only ones. While the EICA hypothesis undoubtedly stimulated much of the recent research on evolution in invasive plants, many other hypotheses about evolutionary change in invasive plants are possible (e.g. Baker 1974; Brown and Marshall 1981; Callaway and Ridenour 2004; Müller-Schärer and Steinger 2004). Genetic differentiation in introduced populations may occur in any ecological trait that is beneficial under the novel selection conditions, given that there is genetic variation for it. A straightforward way of testing such hypotheses about adaptive evolutionary change is to compare offspring from native and introduced populations in a common environment. If under identical conditions native and introduced populations differ significantly in the ecological characteristic(s) of interest, then this is evidence for genetic differentiation.

Another avenue of research is the analysis of neutral genetic variation among and between native and introduced populations with DNA markers or allozymes. Molecular markers are important tools in the context of plant invasions, because they provide information about invasion pathways and the amount of genetic variation introduced. After all, the potential for adaptive evolutionary change in an invasive species depends on the amount of genetic variation introduced (Brown and Marshall 1981; Barrett and Husband 1990). On the other hand, if introduced species are severely genetically impoverished, they may undergo a phase of inbreeding, with a greater likelihood of evolution by genetic drift, before they are able to spread (Barrett and Husband 1990). Ultimately, therefore, a combination of field, molecular marker, and common garden studies is needed to fully understand evolutionary change in an invasive species. Field comparisons must establish whether there is actually a (phenotypic) pattern of difference between native and introduced populations. Common garden studies can then be used to test whether this observed pattern has a genetic basis, and molecular studies will give an idea of the roles that drift versus adaptive evolution have played in creating this genetic difference.

Here, we review the current empirical evidence for phenotypic and genetic differentiation between native and introduced populations, discuss some of the general methodological problems associated with cross-continental comparisons, and make suggestions for future research.

\section{Literature analysis}

In order to review all currently available data about comparisons of native versus introduced plant populations, we carried out an extensive literature search, using databases (Web of Science, Biological Abstracts) and references in published papers. In addition, we included a number of unpublished studies. A study was included if comparisons were made between continents or disjunct areas within continents, and if the data from native and introduced populations were collected by the same author(s) according to the same protocol. Cases of range expansion were not considered. For each species and 
independent study we created one record, i.e. several data records were possible for the same species, if obtained from different experiments. Only one record was created where several papers had been published using the same data.

We compiled four different data sets: (1) field studies that compared plant sizes, fecundities, herbivore loads or attack rates, or population sizes in the native and introduced range; (2) molecular studies that addressed neutral genetic variation among and between native and introduced populations with DNA markers or allozymes; (3) common garden or greenhouse experiments that compared quantitative traits in offspring from native and introduced populations; (4) experiments that addressed phenotypic plasticity in native versus introduced populations. In the third category, the majority of studies were tests of the EICA hypothesis, i.e. comparisons of plant growth, competitive ability, plant resistance and tolerance. The results of the plasticity studies were presented separately, because they had nothing to do with the EICA hypothesis and in each case additional information was needed about the environmental factors manipulated.

\section{Comparisons of native and introduced populations in the field}

We found eleven published studies that compared native and introduced populations in the field (Table 1). One of these (Fenner and Lee 2001) compared herbivore attack rates across continents in 13 different Asteraceae species, so there were 23 independent comparisons in total. The article by Fenner and Lee (2001) provided no statistical comparisons of native and introduced populations. However, it presented the data for each species and population, so we could calculate a Wilcoxon rank sum test for overall difference between native and introduced populations in each species. Out of the six studies that estimated population sizes, three found that populations were larger in the introduced range and three found that they did not differ from native populations. In addition, seven out of nine comparisons of individual plant sizes or fecundities showed that plants performed better in introduced populations, and 8 out of 18 comparisons of herbivore impacts found that there were decreased herbivore loads or attack rates in the invasive range. Except for one study (Vilà et al. 2005), where in spite of decreased herbivore damage plants from introduced populations were smaller, the opposite results - decreased plant size or increased herbivory in introduced populations-were never found.

Overall, the data from field studies suggest that plants indeed frequently perform better and are less affected by herbivores in the introduced range. This contradicts a recent study by Thèbaud and Simberloff (2001) who compared plant sizes recorded in European and American floral guides and found no general tendency for plants to be taller in their introduced range. A possible reason for this difference could be that people often

Table 1 Field studies that compared population sizes, plant sizes or fecundities, or herbivore impact in native and introduced plant populations

\begin{tabular}{|c|c|c|c|c|c|c|}
\hline Species & $n$ & Population size & Plant size & Plant fecundity & Herbivory & Reference \\
\hline Achillea millefolium & $3 / 3$ & & & & 0 & Fenner and Lee (2001) \\
\hline Bellis perennis & $3 / 3$ & & & & 0 & Fenner and Lee (2001) \\
\hline Carduus nutans & NA & & & + & & Woodburn and Sheppard (1996) \\
\hline Cirsium arvense & $3 / 3$ & & & & 0 & Fenner and Lee (2001) \\
\hline Cirsium vulgare & $3 / 3$ & & & & - & Fenner and Lee (2001) \\
\hline Clidemia hirta & $3 / 3$ & & & & - & DeWalt et al. (2004b) \\
\hline Crepis capillaris & $3 / 3$ & & & & 0 & Fenner and Lee (2001) \\
\hline Cytisus scoparius & $10 / 10$ & & & & - & Memmott et al. (2000) \\
\hline Hieracium pilosella & $3 / 3$ & & & & 0 & Fenner and Lee (2001) \\
\hline Hypericum perforatum & $40 / 25$ & 0 & - & & - & Vilà et al. (2005) \\
\hline Hypochaeris radicata & $3 / 3$ & & & & 0 & Fenner and Lee (2001) \\
\hline Lapsana communis & $3 / 3$ & & & & 0 & Fenner and Lee (2001) \\
\hline Leucanthemum vulgare & $3 / 3$ & & & & - & Fenner and Lee (2001) \\
\hline Lythrum salicaria & $5 / 6$ & & & + & & Edwards et al. (1998) \\
\hline Lythrum salicaria & $102 / 102$ & + & & & & Eckert et al. (1996) \\
\hline Rhododendron ponticum & $6 / 6^{\mathrm{a}}$ & 0 & + & 0 & & Erfmeier and Bruelheide (2004) \\
\hline Senecio inaequidens & $18 / 5-10$ & + & + & + & - & Prati and Bossdorf (2004a) \\
\hline Senecio jacobaea & $3 / 3$ & & & & 0 & Fenner and Lee (2001) \\
\hline Senecio vulgaris & $3 / 3$ & & & & 0 & Fenner and Lee (2001) \\
\hline Silene latifolia & $50 / 36$ & 0 & & & - & Wolfe (2002) \\
\hline Solidago gigantea & $46 / 45$ & + & + & + & & Jakobs et al. (2004) \\
\hline Taraxacum officinale & $3 / 3$ & & & & 0 & Fenner and Lee (2001) \\
\hline Tripleurospermum inodorum & $3 / 3$ & & & & - & Fenner and Lee (2001) \\
\hline
\end{tabular}

"+" indicates an increase in the introduced range, relative to the native range, "-" a decrease in the introduced range and " 0 " that there was no difference between native and introduced populations

$N A$ not available $n$ the numbers of native/introduced populations studied

${ }^{a}$ Only native Georgian populations considered 
chose to study problematic pest species, such as Lythrum salicaria in North America or Solidago gigantea in Europe, while the study of Thébaud and Simberloff (2001) was based on all species listed, including established but inconspicuous ones. The currently existing field data might be a non-random sample out of all introduced species.

The majority of the field studies that quantified some aspect of herbivore impact support the idea of an enemy release in introduced populations (Table 1). The results from cross-continental comparisons are thus in accordance with a recent database study across 473 herbaceous plant species, which showed that plant pathogens are often less diverse in introduced plant populations, and the degree of this loss of pathogens is positively correlated with the invasion status of a species (Mitchell and Power 2003). So far one study alone (Memmott et al. 2000) has distinguished between specialist and generalist herbivores and found only the specialists to be fewer in the introduced range. It is surprising that not more studies have taken this approach, given the different expectations about specialist and generalist herbivores (Keane and Crawley 2002; Bossdorf et al. 2004b).

\section{Neutral genetic variation in native versus introduced populations}

The data from studies with DNA markers or allozymes must be treated with caution because there were great differences in how genetic diversity and genetic differentiation between populations were calculated. In addition, some studies used both DNA markers and allozymes simultaneously. Therefore, to interpret these heterogeneous data, several measures, such as F-statistics, AMOVA, and simple descriptive statistics, as well as different types of markers, had to be considered together.

We found 13 independent analyses of neutral genetic variation that involved 11 different species (Table 2). Out of 13 comparisons of within-population genetic diversity, the diversity of introduced populations was reduced in four cases and increased in two cases. It appears therefore that plant invasions are not as frequently associated with overall genetic bottlenecks as previously suggested by some authors (Brown and Marshall 1981; Barrett and Husband 1990). Genetic differentiation among populations was lower in the introduced range in five out of six studies (Table 2). Nonetheless, most studies suggest that multiple introductions have occurred. In Rubus alceifolius, single introductions occurred on several Indian Ocean islands on which the species spread by apomixis (Amsellen et al. 2001). For Senecio inaequidens, there were at least two independent introductions to Europe (Lafuma 2003). Overall, multiple introductions of invasive plants seem to be the rule rather than the exception and are common particularly in North America.

Molecular markers are important tools in the context of biological invasions because they provide information about pathways of introduction and the amount of genetic variation introduced (Barrett and Shore 1989; Sakai et al. 2001). The latter, in particular, influences a species' potential for post-invasion evolution and at the

Table 2 Comparisons of neutral genetic variation in native versus introduced plant populations, using DNA markers or allozymes, that provide information about genetic diversity and/or population differentiation in both ranges, or about the numbers of introductions

\begin{tabular}{|c|c|c|c|c|c|c|c|}
\hline Species & Life history & Marker & $n$ & $\begin{array}{l}\text { Genetic } \\
\text { diversity }^{\mathrm{a}}\end{array}$ & $\begin{array}{l}\text { Population } \\
\text { differentiation }\end{array}$ & $\begin{array}{l}\text { Number } \\
\text { of introductions }\end{array}$ & Reference \\
\hline Alliaria petiolata & Biennial, selfing & ISSR & $3 / 8$ & 0 & & & Meekins et al. 2001 \\
\hline Alliaria petiolata & Biennial, selfing & Microsatellites & s $27 / 25$ & - & 0 & Multiple & Durka et al. 2005 \\
\hline Apera spica-venti & $\begin{array}{l}\text { Annual, } \\
\text { outcrossing }\end{array}$ & Isozymes & $6 / 9$ & 0 & - & Multiple & Warwick et al. 1987 \\
\hline Bromus mollis & Annual, selfing & Isozymes & $10 / 10$ & 0 & & & Brown and Marshall 1981 \\
\hline Bromus tectorum & Annual, selfing & Isozymes & $51 / 60$ & - & - & Multiple & $\begin{array}{l}\text { Novak et al. 1991,Novak } \\
\text { and Mack } 1993\end{array}$ \\
\hline Capsella bursa-pastoris & Biennial, selfing & Isozymes & $593 / 88$ & 0 & & Multiple & Neuffer and Hurka 1999 \\
\hline Clidemia hirta & Perennial, mixed & Isozymes & $20 / 20$ & + & - & & DeWalt and Hamrick 2004 \\
\hline Epipactis helleborine & Perennial, mixed & $\begin{array}{l}\text { Isozymes } \\
\text { cpDNA }\end{array}$ & $\begin{array}{l}35 / 12 \\
17 / 12\end{array}$ & $\begin{array}{l}+ \\
+\end{array}$ & $\begin{array}{l}- \\
-\end{array}$ & & Squirrell et al. 2001 \\
\hline Hypericum perforatum & $\begin{array}{l}\text { Perennial, } \\
\text { outcrossing }\end{array}$ & AFLP & $18 / 32$ & 0 & & Multiple & Maron et al. 2004 \\
\hline Rhododendron ponticum & $\begin{array}{l}\text { Perennial, } \\
\text { outcrossing }\end{array}$ & AFLP & $30 / 21$ & 0 & & & Ross 2003 \\
\hline Rubus alceifolius & Perennial, apomict & AFLP & $16 / 16$ & - & - & Single & Amsellem et al. 2000 \\
\hline $\begin{array}{l}\text { Senecio inaequidens } \\
\text { (Belgium introduction) }\end{array}$ & $\begin{array}{l}\text { Perennial, } \\
\text { outcrossing }\end{array}$ & $\begin{array}{l}\text { Isozymes } \\
\text { cpDNA }\end{array}$ & $2 / 2$ & $\begin{array}{l}0 \\
-\end{array}$ & & & Lafuma 2003 \\
\hline $\begin{array}{l}\text { Senecio inaequidens } \\
\text { (S France introduction) }\end{array}$ & $\begin{array}{l}\text { Perennial, } \\
\text { outcrossing }\end{array}$ & $\begin{array}{l}\text { Isozymes } \\
\text { cpDNA }\end{array}$ & $2 / 2$ & $\begin{array}{l}0 \\
0\end{array}$ & & & Lafuma 2003 \\
\hline
\end{tabular}

" + " indicates an increase in the introduced range, relative to the native range, "_" a decrease in the introduced range, and " 0 " that there was no difference between native and introduced populations $n$ the numbers of native/introduced populations studied

${ }^{a}$ Number and percentage of polymorphic loci, or genetic diversity from AMOVA, or Shannon diversity indices

${ }^{\mathrm{b}} F_{\text {st }}$ or $G_{\text {st }}$ values 
same time the extent to which founder effects may have contributed to evolutionary change. Molecular data are important both for choosing appropriate controls in common garden studies (see below) and for interpreting their results, and should therefore be regarded as complementary to common garden studies.

In addition to the studies reviewed here, there are many more published studies that analyzed neutral genetic variation only among introduced populations (e.g. Saltonstall 2003; Walker et al. 2003). Often they found overall genetic variation to be low, and explained this as due to a genetic bottleneck during introduction. However, without a comparison to native populations one cannot draw a legitimate conclusion about the role of genetic bottlenecks or about pathways of introduction.

\section{Comparisons of quantitative traits in a common environment}

We found a total of 45 independent studies that compared quantitative traits in native versus introduced populations of 24 different plant species (Tables 3, 4). The most commonly employed methods were common garden experiments (26 comparisons), herbivore bioassays (13 comparisons), and greenhouse experiments (12 comparisons). Many of the studies used more than one method and/or addressed different categories of traits (Table 3). The majority of previous studies were tests of the EICA hypothesis that compared growth (36 comparisons) or resistance (22 comparisons) between native and introduced populations. In contrast, only six studies addressed competitive ability and six studies addressed tolerance to herbivory. Increased growth was found in 20 out of 36 studies and decreased resistance was found in 12 out of 22 studies, whereas contradictory results were rare (Table 3). To date, only 19 studies fully tested the EICA hypothesis by addressing both growth and defence in the same model system. Eight of these found support for EICA, whereas in others the results were ambiguous (Table 3). Note that the decreased growth of Sapium sebiferum in the presence of herbivores from its native range (Siemann and Rogers 2003a) is consistent with the predictions of EICA and indeed is strong evidence for a role of local herbivore preferences in determining the success of plants from native versus introduced ranges.

The evolution of increased competitive ability (EICA) hypothesis predicts that, when compared to native populations, plants from introduced populations will show increased growth (or competitive ability) and at the same time, decreased resistance to natural enemies (Blossey and Nötzold 1995). Here, increased growth was found in $56 \%$ of the reviewed studies ( 9 out of 20 species) and decreased resistance was found in $55 \%$ of the reviewed studies ( 7 out of 14 species), which might be interpreted as overall moderate support for EICA. The picture changes, however, if we consider only the 17 complete tests of the EICA hypothesis. Only seven of these are fully in accordance with the EICA predictions. In the other cases, there is often support for one aspect of the EICA hypothesis, but not for the other.

Previous EICA studies sometimes measured plant growth under conditions in which competitors were absent or suppressed. Growth in the absence of competition might not be an adequate measure of invasiveness if the ability of a plant to rapidly exploit readily available resources is not positively correlated with its ability to tolerate low resource levels relative to native competitors (Grime 1979; Tilman 1982; Goldberg 1996). Many plants invade natural communities where they experience both intra- and inter-specific competition (e.g. Alliaria petiolata, Hypericum perforatum). In such cases, growth in isolation may not be a reasonable estimate of the plant's invasive potential. It would not be a good predictor for those species that invade manmade, disturbed habitats either (such as Senecio jacobaea, Solidago canadensis) because these often form thick monospecific stands with a high intensity of intraspecific competition. Studies that compared native and introduced populations under competitive conditions found no consistent pattern for plant performance (Table 3).

Admittedly, a problem with competition experiments is the choice of appropriate competitors. Plants encounter different sets of competitors in their native and introduced ranges and they may be adapted to some extent to their native ones (Callaway and Aschehoug 2000; Hierro et al. 2005). One solution to this might be intraspecific competition experiments (Bossdorf et al. 2004a). If interspecific competitors are used, these should be species that actually co-occur with the invasive species in its introduced range. The best, albeit very laborious, solution is to do replicated, reciprocal transplant experiments across continents (Willis and Blossey 1999; Maron et al. 2004).

Another limitation of previous studies is that plant defence was often tested in bioassays with generalist herbivores. However, introduced plants are mostly released from specialist herbivores in their introduced range (Memmott et al. 2000; Keane and Crawley 2002) and the EICA hypothesis assumed this in generating its predictions (Blossey and Nötzold 1995). Because resistance against specialists and generalists is likely based on different mechanisms (Van der Meijden 1996), studies that address both simultaneously may find different results (Bossdorf et al. 2004b). Finally, while plant resistance has previously received much attention, plant tolerance, another important component of plant defence, has not (Müller-Schärer and Steinger 2004). Future tests of the EICA hypothesis should be performed more frequently under competitive conditions, i.e. in the presence of either intra- or interspecific competitors, and greater emphasis should be put on resistance to specialist herbivores and plant tolerance.

Overall, most previous studies of quantitative traits in native versus introduced populations demonstrated some sort of genetic divergence between plant popula- 
Table 3 Experiments that compared growth $(\mathrm{G})$, competitive ability $(\mathrm{C})$, resistance $(\mathrm{R})$, or tolerance $(\mathrm{T})$ between native and introduced plant populations

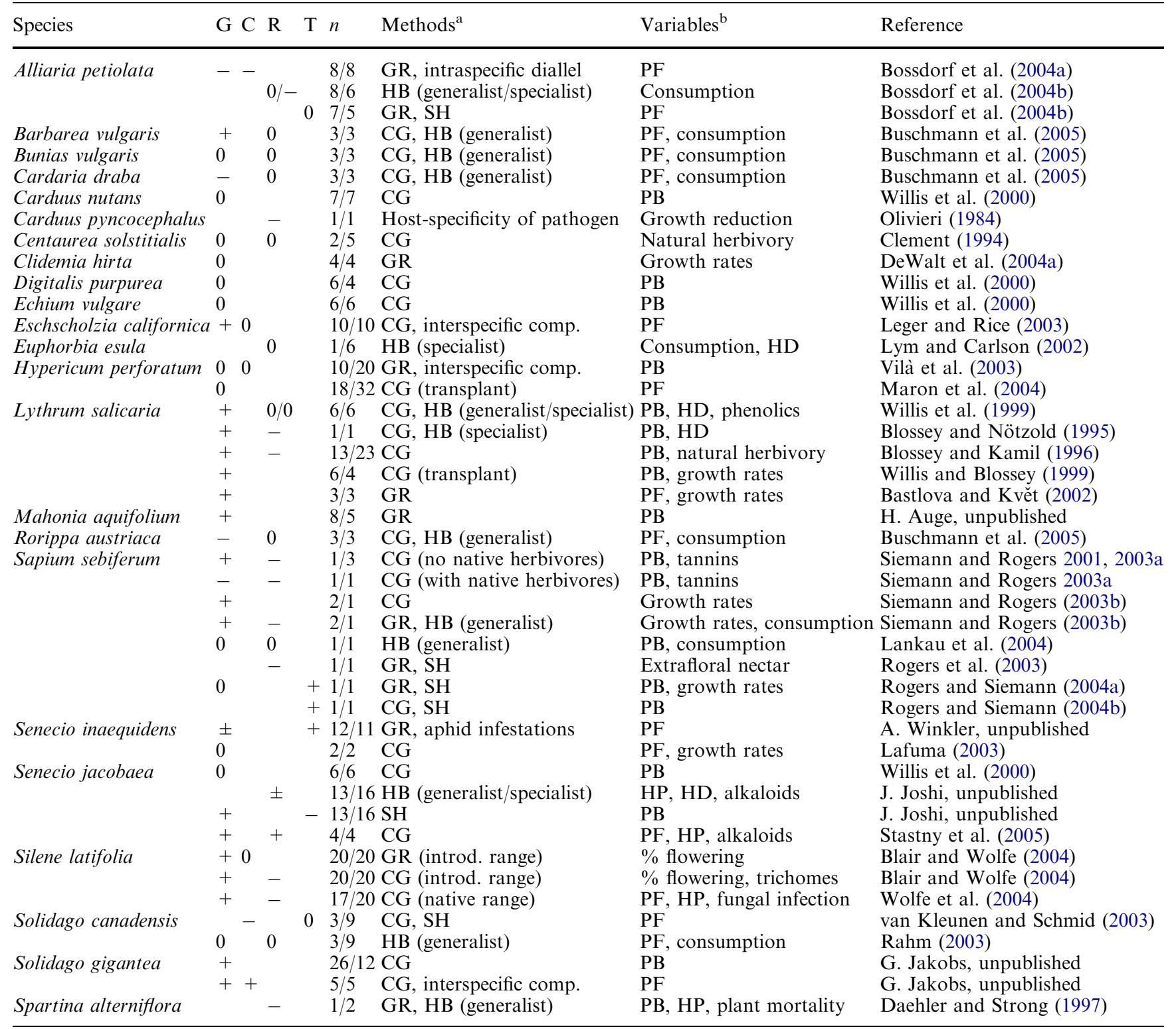

Each line represents an independent experiment

"+" indicates an increase in the introduced range, relative to the native range, "-" a decrease in the invasive range, and " 0 " that there was no difference between native and introduced populations $G$ comparisons of plant growth or fitness in a competition-free environment, Ccomparisons of plant growth or fitness in the presence of intra- or interspecific competitors, $R$ direct comparisons of physical or chemical resistance traits, or indirect estimates of plant resistance through palatability tests or other measures of

tions in the native and the introduced ranges. Rapid evolutionary change therefore appears to be fairly common in plant invasions. In any case, these changes may be a result of adaptive evolution, genetic drift, founder effects or any combination of these causes. Because of a lack of molecular data and incomplete knowledge of source populations, it is often not possible to disentangle these processes. herbivore preference or performance, $T$ experiments that measured the capacity of plants to compensate for natural or simulated herbivore damage by regrowth and $n$ the numbers of native/invasive populations studied

${ }^{\text {a }} C G$ common garden, $G R$ greenhouse, $H B$ herbivore bioassay, $S H$ simulated herbivory

${ }^{\mathrm{b}} H D$ herbivore development, $H P$ herbivore preference, $P B$ plant biomass, $P F$ plant fecundity

\section{Phenotypic plasticity in native versus introduced populations}

We found ten studies that compared phenotypic plasticity in native versus introduced plant populations (Table 4). Most of these manipulated light or nutrient availability. In five out of the ten studies, introduced 
populations were more plastic than native populations (Table 4). One explanation for this might be that plasticity allows introduced species to naturalize across a range of environments. Plastic, "general-purpose genotypes" could have a fitness advantage in founder populations where local adaptation has not occurred yet (Baker 1974; Sexton et al. 2002), or cannot occur because of a lack of genetic variation. Hence there might have been an evolutionary "sorting out" (Müller-Schärer and Steinger 2004) of more plastic genotypes. Alternatively, adaptive post-invasion evolution of increased plasticity might have occurred where introduced populations were not genetically impoverished, and sufficient genetic variation for plasticity existed.

\section{Methodological problems}

When comparing plant populations from the native and the introduced range, an important question is whether we are comparing the appropriate taxonomic units. Species often vary in their chromosome numbers and in some cases only one ploidy level is invasive (Brown and Marshall 1981; Barrett and Richardson 1986). For instance, the South African ragwort Senecio inaequidens occurs in diploid and tetraploid populations in its native range, but all introduced European populations are tetraploid (Lafuma et al. 2003). To investigate evolutionary change during the invasion of this species, comparisons should therefore be restricted to tetraploids. However, if both diploids and tetraploids have been introduced initially, but only the tetraploids became invasive, a comparison between the two types may provide insight into early sorting-out of invasiveness traits that are associated with the level of ploidy. Other examples where only one ploidy level of a species has become invasive include Butomus umbellatus (Eckert et al. 2000) and Centaurea maculosa (Müller 1989) in
North America, and Solidago gigantea (Jakobs et al. 2004) in Europe.

A related problem occurs when invaders hybridize, either intraspecifically among formerly distant genotypes or with different species. Many ornamental species have been deliberately crossed and selected to produced a variety of cultivars, some of which have escaped to become invasive (e.g. Mahonia aquifolium). Natural or deliberate hybridization has been recognized as an important component of evolutionary change in introduced plants (Brown and Marshall 1981; Ellstand and Schierenbeck 2000; Milne and Abbott 2000). However, comparisons between native and introduced populations will obviously make little sense in such cases. Instead, it will be more informative to compare the traits of invasive and non-invasive cultivars or of invasive hybrids and their non-invasive parent species (e.g. Weber and D'Antonio 1998).

In this review we did not include range expansion, i.e. cases where species spread into novel areas adjacent to the ones already occupied. Although such species are often listed as introduced in many floras, we excluded them because we believe that range expansion does not share some of the unique features of cross-continental introductions. Range expansion is often a natural process. Cross-continental introductions, in contrast, are mostly caused by humans, and they add the important dimension of crossing biogeographic barriers (Mooney and Cleland 2001). Species introduced to other continents face a novel set of competitors, mutualists, and antagonists with which they have not coevolved (Callaway and Aschehoug 2000), therefore we regard crosscontinental introductions as fundamentally different from range expansions. Comparisons of populations from the centre of a distribution range to those from its margins may provide insights into the nature of plant colonization and adaptation (Durka 1999) just as comparisons of mainland and island populations are infor-

Table 4 Experiments that compared phenotypic plasticity in native versus invasive plant populations

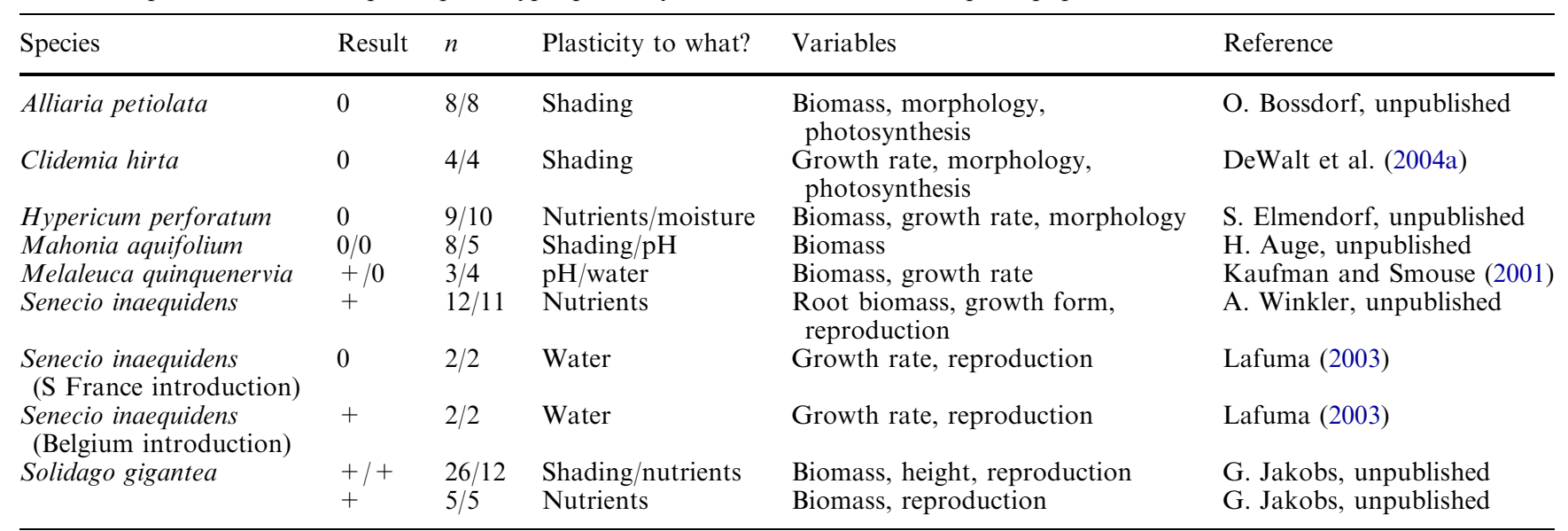

" $+"$ indicates greater plasticity in introduced populations, relative to native populations, "_, reduced plasticity in introduced populations, " 0 " that there was no difference between native and introduced populations $n$ the numbers of native/invasive populations studied 
mative (Husband and Barrett 1991; Cody and Overton 1996), but we considered them to be outside of the scope of this review.

Common garden studies that use seeds from wild populations may provide inaccurate estimates of population differentiation, particularly for early traits, due to environmental maternal effects (Roach and Wulff 1987). Except for van Kleunen and Schmid (2003), none of the studies in Tables 3 and 4 controlled for such effects by pre-cultivating plants for one or several generations before the comparisons were made. Some studies did include seed mass or certain parent plant traits as covariates, or used seeds from multiple years or habitats to evaluate non-genetic effects mediated through seed provisioning differences. Still, if there are systematic differences between the native and the introduced range that can be carried over to the next generation via seed quality and cannot be approximated by such methods, this might cause misinterpretation of cross-continental studies.

In general, cross-continental comparisons are strengthened by large samples of native and introduced populations. Sample size should be as high as possible, because it increases statistical power for testing continent effects. Alternatively, if the invasion history of a species is well known, one might study a chronological sequence of introduced populations (Barrett and Shore 1989; Daehler and Strong 1997; Siemann and Rogers 2001) or, if there has been a single introduction only, compare the known founder population to other, younger populations in the introduced range. However, multiple introductions appear to be the rule rather than the exception (Table 2), so lacking any historical information a large sample size should be the default solution.

\section{Conclusions and directions for future research}

The ability of introduced plants to adapt to novel environments is often invoked with little detail on which environmental factors are expected to be novel. Many plants occur in similar climatic and edaphic conditions in their native and introduced ranges (Williamson 1996), so selection will more likely be exerted by novel competitors, mutualists, or antagonists (but see Maron et al. 2004). The documentation of such differences in interactions, however, has been very limited so far. For instance, herbivore loads in native and introduced ranges were addressed in only five studies (Table 1). More comparative field studies are needed to connect genetic differences in the common garden with phenotypic differences and ecological processes in the field.

Until now, alternative explanations for increased vigour in introduced plant populations have received little attention. For instance, many invasive plants have been introduced originally as ornamentals (Mack and Lonsdale 2001). It is not unlikely that some of them are more vigorous as invaders, when compared to natural populations in the native range, because they have been selected for size by humans (Crawley et al. 1996). Reduced herbivore resistance - as predicted by the EICA hypothesis - could also be the consequence of a history of insecticide spraying, particularly in invasive agricultural weeds, rather than of a general absence of herbivores. The purging of deleterious recessive alleles in small founder populations may also account at least partly for their success. If small populations are common in early stages of introductions and deleterious recessive alleles that become homozygous mainly account for inbreeding depression, then natural selection can remove these alleles more effectively than in large populations (Lynch and Walsh 1998). Moreover, population bottlenecks can convert epistatic variation into additive genetic variation and thus increase a population's potential for adaptation (e.g. Fenster et al. 1997; Naciri-Graven and Goudet 2003). Both of these genetic mechanisms would explain the frequently observed time lag between introduction and spread as well as the subsequent increase in fitness, but they have never been tested explicitly in the context of plant invasions.

While the EICA hypothesis undoubtedly stimulated much of the recent research on evolution in invasive plants, other hypotheses of evolutionary change in invasive plants have been proposed (e.g. Baker 1974; Brown and Marshall 1981; Bossdorf et al. 2004a; Callaway and Ridenour 2004; Müller-Schärer and Steinger 2004). Genetic differentiation in introduced populations may occur for any trait that is favored under the novel selection conditions given that there is genetic variation for it. For instance, Buckley et al. (2003) studied seed size variation in native versus introduced populations of two introduced shrubs. They found that the seeds of Cytisus scoparius were heavier in introduced populations, but that there was no change of seed size in the introduced range of Ulex europaeus. This study has been a valuable step towards a more general approach of testing for evolutionary change in traits commonly associated with weediness (Baker 1965, 1974).

Müller-Schärer and Steinger (2004) proposed an evolutionary change in plant life cycles towards polycarpy in the introduced range, driven by herbivore preference for larger individuals that favours early reproduction and monocarpy. The release from enemies, in turn, may result in a selective advantage of polycarpic genotypes in the introduced range. A trend towards polycarpy has been observed in several introduced plants including Cynoglossum officinale, Senecio jacobaea, and Centaurea stoebe (see Müller-Schärer and Steinger 2004, and references therein).

Introduced plants may dominate invaded communities through allelopathic inhibition of competitors (Callaway and Aschehoug 2000; Bais et al. 2003) or through manipulation of the mycorrhizal community and other micro-organisms in the soil. In fact, some introduced species appear to "cultivate" a soil community suitable for their own proliferation (Klironomos 2002). If belowground interactions play a key role in 
plant invasions, as suggested recently (Klironomos 2002; Reinhart et al. 2003; Callaway et al. 2004), there may be the potential for evolutionary change. For instance, Prati and Bossdorf (2004b) investigated allelopathic interactions between native and introduced populations of Alliaria petiolata and two co-occurring Geum species, one from Europe and one from North America. They found that the germination rates of both species were reduced if plants from native Alliaria populations had contaminated the soil with root exudates. However, only the North American Geum species was inhibited when the soil had been contaminated by plants from introduced Alliaria populations. Their results suggested a genetically based change of allelopathic potential in introduced populations of Alliaria petiolata and demonstrated that the importance of allelopathy may depend on the origins of both interacting species. The reversal of relative genotype success in Sapium sebiferum depending on whether herbivores from Asia (native range) were present or absent (Siemann and Rogers 2003a), also suggests that the identity of species that interact with invasive plants is critical in determining the conditions under which genetic adaptations are likely to enhance invasive success.

Acknowledgements This review originated from a workshop on evolution in invasions that was financially supported by the ESF European Science Foundation, the Stiftung Allgemeine Hypothekenbank, and the UFZ Centre for Environmental Research. WER and ES were supported by the US NSF, US EPA and USDA. We are grateful to Sarah Elmendorf, Gabi Jakobs, Jasmin Joshi, Annett Winkler for their unpublished data, and to Saara DeWalt for her thoughtful comments. Comments by Christian Körner and two anonymous reviewers greatly improved the quality of this manuscript.

\section{References}

Amsellem L, Noyer JL, Le Bourgeois T, Hossaert-McKey M (2000) Comparison of genetic diversity of the invasive weed Rubus alceifolius Poir. (Rosaceae) in its native range and in areas of introduction, using amplified fragment length polymorphism (AFLP) markers. Mol Ecol 9:443-455

Amsellem L, Noyer JL, Hossaert-McKey M (2001) Evidence for a switch in the reproductive biology of Rubus alceifolius (Rosaceae) towards apomixis, between its native range and its area of introduction. Am J Bot 88:2243-2251

Bais HP, Vepachedu R, Gilroy S, Callaway RM, Vivanco JM (2003) Allelopathy and plant invasions: from molecules to genes to species interactions. Science 301:1377-1380

Baker HG (1965) Characteristics and modes of origin of weeds. In: Baker HG, Stebbins GL (eds) The genetics of colonizing species. Academic, New York, pp 147-169

Baker HG (1974) The evolution of weeds. Annu Rev Ecol Syst 5:124

Barrett SCH, Husband BC (1990) Genetics of plant migration and colonization. In: Brown AHD, Clegg MT, Kahler AL, Weir BS (eds) Plant population genetics, breeding, and genetic resources. Sinauer, Sunderland, pp 254-277

Barrett SCH, Shore JS (1989) Isozyme variation in colonizing plants. In: Soltis D, Soltis P (eds) Isozymes in plant biology. Dioscorides, Portland, pp 106-126

Bastlova D, Květ J (2002) Differences in dry weight partitioning and flowering phenology between native and non-native plants of purple lossestrife (Lythrum salicaria L.). Flora 197:332-340
Blair AC, Wolfe LM (2004) The evolution of an invasive plant: an experimental study with Silene latifolia. Ecology 85:3035-3042

Blossey B, Kamil J (1996) What determines the increased competitive ability of invasive non-indigenous plants?. In: Moran VC, Hoffmann JH (eds) Proceedings of the IX international symposium on the biological control of weeds. University of Cape Town, Stellenbosch, pp 3-9

Blossey B, Nötzold R (1995) Evolution of increased competitive ability in invasive non-indigenous plants: a hypothesis. J Ecol 83:887-889

Bossdorf O, Prati D, Auge H, Schmid B (2004a) Reduced competitive ability in an invasive plant. Ecol Lett 7:346-353

Bossdorf O, Schröder S, Prati D, Auge H (2004b) Palatability and tolerance to simulated herbivory in native and introduced populations of Alliaria petiolata (Brassicaceae). Am J Bot 91:856-862

Brown AHD, Marshall DR (1981) Evolutionary changes accompanying colonization in plants. In: Scudder GGE, Reveal JL (eds) Evolution today. Carnegie-Mellon University, Pittsburg, pp 351-363

Buckley YM, Downey P, Fowler SV, Hill R, Memmott J, Norambuena H, Pitcairn M, Shaw R, Sheppard AW, Winks C, Wittenberg R, Rees M (2003) Are invasives bigger? A global study of seed size variation in two invasive shrubs. Ecology 84:1434-1440

Buschmann H, Edwards PJ, Dietz H (2005) Variation in growth pattern and response to slug damage among native and invasive provenances of four perennial Brassicaceae species. J Ecol (in press)

Callaway RM, Aschehoug ET (2000) Invasive plants versus their new and old neighbors: a mechanism for exotic invasion. Science 290:521-523

Callaway RM, Ridenour (2004) Novel weapons: invasive success and the evolution of increased competitive ability. Front Ecol Environ 2:436-442

Callaway RM, Thelen GC, Rodriguez A, Holben WE (2004) Soil biota and exotic plant invasion. Nature 427:731-733

Clement SL (1994) Resistance among populations of yellow starthistle to thistle-head insects: results from garden plots in Italy. Biol Control 4:149-156

Cody ML, Overton JM (1996) Short-term evolution of reduced dispersal in island plant populations. J Ecol 84:53-61

Crawley MJ (1987) What makes a community invasible?. In: Gray AJ, Crawley MJ, Edwards PJ (eds) Colonisation, succession and stability. Blackwell, London, pp 429-453

Crawley MJ, Harvey PH, Purvis A (1996) Comparative ecology of the native and alien floras of the British Isles. Phil Trans R Soc Lond B 351:1251-1259

Daehler CC, Strong DR (1997) Reduced herbivore resistance in introduced smooth cordgrass (Spartina alterniflora) after a century of herbivore-free growth. Oecologia 110:99-108

DeWalt SJ, Denslow JS, Hamrick JL (2004a) Biomass allocation, growth, and photosynthesis of genotypes from native and introduced ranges of the tropical shrub Clidemia hirta. Oecologia 138:121-131

DeWalt SJ, Hamrick JL (2004) Genetic variation of introduced Hawaiian and native Costa Rican populations of an invasive tropical shrub, Clidemia hirta. Am J Bot 91:1155-1162

DeWalt SJ, Denslow JS, Ickes K (2004b) Natural-enemy release facilitates habitat expansion of the invasive tropical shrub Clidemia hirta. Ecology 85:471-483

Drake JA, Mooney HA, di Castri F, Groves RH, Kruger FJ, Rejmánek M, Williamson M (1989) Biological invasions: a global perspective. Wiley, Chichester

Durka W (1999) Genetic diversity in peripheral and subcentral populations of Corrigiola litoralis L. (Illecebraceae). Heredity 83:476-484

Durka W, Bossdorf O, Prati D, Auge H (2005) Molecular evidence for multiple introductions of Alliaria petiolata to North America. Mol Ecol (in press)

Eckert CG, Manicacci D, Barrett SCH (1996) Genetic drift and founder effect in native versus introduced populations of an 
invading plant, Lythrum salicaria (Lythraceae). Evolution 50:1512-1519

Eckert CG, Massonnet B, Thomas JJ (2000) Variation in sexual reproduction among introduced populations of flowering rush, Butomus umbellatus (Butomaceae). Can J Bot 78:437-446

Edwards KR, Adams MS, Květ J (1998) Differences between European native and American invasive populations of $L y$ thrum salicaria. Appl Veg Sci 1:267-280

Ellstrand NC, Schierenbeck KA (2000) Hybridization as a stimulus for the evolution of invasiveness in plants? Proc Natl Acad Sci USA 97:7043-7050

Erfmeier A, Bruelheide H (2004) Comparison of native and invasive Rhododendron ponticum populations: growth, reproduction and morphology under field conditions. Flora 199:120-133

Fenner M, Lee WG (2001) Lack of pre-dispersal seed predators in introduced Asteraceae in New Zealand. N Z J Ecol 25:9599

Fenster CB, Galloway LF, Chao L (1997) Epistasis and its consequences for the evolution of natural populations. Trends Ecol Evol 12:282-286

Gilpin M (1990) Ecological prediction. Science 248:88-89

Goldberg DE (1996) Competitive ability: definitions, contingency and correlated traits. Phil Trans R Soc Lond B 351:1377-1385

Grime JP (1979) Plant strategies and vegetation processes. Wiley, Chichester

Hänfling B, Kollmann J (2002) An evolutionary perspective on biological invasions. Trends Ecol Evol 17:545-546

Hierro JL, Maron JL, Callaway RM (2005) A biogeographical approach to plant invasions: the importance of studying exotics in their introduced and native range. $\mathbf{J}$ Ecol 93:5-15

Husband BC, Barrett SCH (1991) Colonization history and population genetic structure in Eichhornia paniculata. Heredity 66:287-296

Jakobs G, Weber E, Edwards PJ (2004) Introduced plants of the invasive Solidago gigantea (Asteraceae) are larger and grow denser than conspecifics in the native range. Divers Distrib 10:11-19

Kaufman SR, Smouse PE (2001) Comparing indigenous and introduced populations of Melaleuca quiquenervia (Cav.) Blake: response of seedlings to water and $\mathrm{pH}$ levels. Oecologia 127:487-494

Keane RM, Crawley MJ (2002) Exotic plant invasions and the enemy release hypothesis. Trends Ecol Evol 17:164-170

van Kleunen M, Schmid B (2003) No evidence for an evolutionary increased competitive ability (EICA) in an invasive plant. Ecology 84:2816-2823

Klironomos JN (2002). Feedback with soil biota contributes to plant rarity and invasiveness in communities. Nature 417:67-70

Kowarik I (1995) Time lags in biological invasions with regard to the succes and failure of alien species. In: Pysek P, Prach K, Rejmanek M, Wade M (eds) Plant invasions: general aspects and special problems. SPB Academic, Amsterdam, pp 14-38

Lafuma L (2003) L'invasion de Senecio inaequidens (Asteraceae) en Europe: une approche evolutive. PhD thesis, Université de Montpellier

Lafuma L, Balkwill K, Imbert E, Verlaque R, Maurice S (2003) Ploidy level and origin of the European invasive weed Senecio inaequidens (Asteraceae). Plant Syst Evol 243:59-72

Lankau RA, Rogers WE, Siemann E (2004) Constraints on the utilisation of the invasive Chinese tallow tree Sapium sebiferum by generalist native herbivores in coastal prairies. Ecol Entomol 29:66-75

Lee CE (2002) Evolutionary genetics of invasive species. Trends Ecol Evol 17:386-391

Leger EA, Rice KJ (2003) Invasive Californian poppies (Eschscholzia californica Cham.) grow larger than native individuals under reduced competition. Ecol Lett 6:257-264

Levine J, Vilà M, D'Antonio CM, Dukes JS, Grigulis K, Lavorel S (2003) Mechanisms underlying the impact of exotic plant invasions. Proc R Soc Lond B 270:775-781

Lodge DM (1993) Biological invasions: lessons for ecology. Trends Ecol Evol 8:133-137
Lonsdale WM (1999) Global patterns of plant invasions and the concept of invasibility. Ecology 80:1522-1536

Lym RG, Carlson RB (2002) Effect of leafy spurge (Euphorbia esula) genotype on feeding damage and reproduction of Aphthona spp.: implications for biological weed control. Biol Control 23:127-133

Lynch M, Walsh B (1998) Genetics and analysis of quantitative traits. Sinauer, Sunderland

Mack RN, Lonsdale WM (2001) Humans as global plant dispersers: getting more than we bargained for. Bioscience 51:95-102

Mack RN, Simberloff D, Lonsdale WM, Evans H, Clout M, Bazzaz FA (2000) Biotic invasions: causes, epidemiology, global consequences, and control. Ecol Appl 10:689-710

Maron JL, Vilà M (2001) When do herbivores affect plant invasions? Evidence for the natural enemies and biotic resistance hypotheses. Oikos 95:361-373

Maron JL, Vilà M, Bommarco R, Elmendorf S, Beardsley P (2004) Rapid evolution of an invasive plant. Ecol Monogr 74:261-280

Meekins JF, Ballard Jr HE, McCarthy BC (2001) Genetic variation and molecular biogeography of a Northern American invasive plant species (Alliaria petiolata, Brassicaceae). Int J Plant Sci 162:161-169

van der Meijden E (1996) Plant defence, an evolutionary dilemma: contrasting effects of (specialist and generalist) herbivores and natural enemies. Entom Exp Appl 80:307-310

Memmott J, Fowler SV, Paynter Q, Sheppard AW, Syrett P (2000) The invertebrate fauna on broom, Cytisus scoparius, in two native and two exotic habitats. Acta Oecol 21:213-222

Milne RI, Abbott RJ (2000) Origin and evolution of invasive naturalized material of Rhododendron ponticum L. in the British Isles. Mol Ecol 9:541-556

Mitchell CE, Power AG (2003) Release of invasive plants from fungal and viral pathogens. Nature 421:625-627

Mooney HA, Cleland EE (2001) The evolutionary impact of invasive species. Proc Natl Acad Sci USA 98:5446-5451

Müller H (1989) Growth pattern of diploid and tetraploid spotted knapweed, Centaurea maculosa Lam. (Compositae) and effects of the root-mining moth Agapeta zoegana (L.) (Lep.: Cochylidae). Weed Res 29:103-111

Müller-Schärer H, Steinger T (2004) Predicting evolutionary change in invasive, exotic plants and its consequences for plantherbivore interactions. In: Ehler LE, Sforza R, Mateille T (eds) Genetics, evolution and biological control. CABI, Wallingford, pp 137-162

Naciri-Graven Y, Goudet J (2003) The additive genetic variance after bottlenecks is affected by the number of loci involved in epistatic interactions. Evolution 57:706-716

Neuffer B, Hurka H (1999) Colonization history and introduction dynamics of Capsella bursa-pastoris (Brassicaceae) in North America: isozymes and quantitative traits. Mol Ecol 8:16671681

Novak SJ, Mack RN (1993) Genetic variation in Bromus tectorum (Poaceae): comparison between native and introduced populations. Heredity 71:167-176

Novak SJ, Mack RN, Soltis DE (1991) Genetic variation in Bromus tectorum: population differentiation in its North American range. Am J Bot 78:1150-1161

Olivieri I (1984) Effect of Puccinia cardui-pycnocephali on slender thistles (Carduus pycnocephalus and C. tenuiflorus). Weed Sci 32:507-510

Perrings C, Williamson M, Dalmazzone S (2000) The economics of biological invasions. Edward Elgar, Cheltenham

Pimentel D, Lach L, Zuniga R, Morrison D (2000) Environmental and economic costs of non-indigenous species in the Unites States. Bioscience 50:53-63

Prati D, Bossdorf O (2004a) A comparison of native and introduced populations of the South African Ragwort Senecio inaequidens DC. in the field. In: Breckle SW, Schweizer B, Fangmeier A (eds) Results of worldwide ecological studies. Verlag Günther Heimbach, Stuttgart, pp 353-359

Prati D, Bossdorf O (2004b) Allelopathic inhibition of germination by Alliaria petiolata (Brassicaceae). Am J Bot 91:285-288 
Rahm S (2003) Comparison of invasive European and native American taxa of the S.canadensis complex, in respect to some taxonomic features and their response to herbivory. Diploma thesis, University of Zurich

Reinhart KO, Packer A, Van der Putten WH, Clay K (2003) Plantsoil biota interactions and spatial distribution of black cherry in its native and invasive ranges. Ecol Lett 6:1046-1050

Reznick DN, Ghalambor CK (2001) The population ecology of contemporary adaptations: what empirical studies reveal about the conditions that promote adaptive evolution. Genetica 112113:183-198

Rice KJ, Mack RN (1991) Ecological genetics of Bromus tectorum. II. Intraspecific variation in phenotypic plasticity. Oecologia 88:84-90

Roach DA, Wulff RD (1987) Maternal effects in plants. Annu Rev Ecol Syst 18:209-236

Rogers WE, Siemann E (2004a) Invasive ecotypes tolerate herbivory more effectively than native ecotypes of the Chinese tallow tree Sapium sebiferum. J Appl Ecol 41:561-570

Rogers WE, Siemann E (2004b) The role of herbivores in alien plant invasions: insights using a combination of methods to enhance or reduce herbivory. In: Weisser WW, Siemann E (eds) Insects and ecosystem function. Springer, Berlin, pp 329-356

Rogers WE, Lankau RA, Siemann E (2003) Damage induced production of extrafloral nectaries in native and introduced seedlings of Chinese tallow tree (Sapium sebiferum). Am Midl Nat 149:413-417

Ross C (2003) Der Anteil der nordamerikanischen Arten Rhododendron catawbiense und Rhododendron maximum an der genetischen Struktur hybridogener Rhododendron ponticumPopulationen in Irland. Diploma thesis, Albrecht-von-HallerInstitut für Pflanzenwissenschaften, University of Göttingen

Sakai A, Allendorf F, Holt JS, Lodge DM, Molofsky J, With KA, Baughman S, Cabin RJ, Cohen JE, Ellstrand NC, Mc Cauley DE, O'Neill P, Parker IM, Thompson JN, Weller SG (2001) The population biology of invasive species. Annu Rev Ecol Syst 32:305-332

Sala OE, Chapin III FS, Armesto JJ, Berlow E, Bloomfield J, Dirzo R, Huber-Sanwald E, Huenneke LF, Jackson RB, Kinzig A, Leemans R, Lodge DM, Mooney HA, Oesterheld M, Poff NL, Sykes MT, Walker BH, Walker M, Wall DH (2000) Global biodiversity scenarios for the year 2100. Science 287:1770-1774

Saltonstall K (2003) Microsatellite variation within and among North American lineages of Phragmites australis. Mol Ecol 12:1689-1702

Sexton JP, McKay JK, Sala A (2002) Plasticity and genetic diversity may allow saltcedar to invade cold climates in North America. Ecol Appl 12:1652-1660

Siemann E, Rogers WE (2001) Genetic differences in growth of an invasive tree species. Ecol Lett 4:514-518

Siemann E, Rogers WE (2003a) Increased competitive ability of an invasive tree my be limited by an invasive beetle. Ecol Appl 13:1503-1507
Siemann E, Rogers WE (2003b) Reduced resistance of invasive varieties of the alien tree Sapium sebiferum to a generalist herbivore. Oecologia 135:451-457

Squirrell J, Hollingsworth PM, Bateman RM, Dickson JH, Light MHS, MacConaill M, Tebbitt MC (2001) Partitioning and diversity of nuclear and organelle markers in native and introduced populations of Epipactis helleborine (Orchidaceae). Am J Bot 88:1409-1418

Stastny M, Schaffner U, Elle E (2005) Do vigour of introduced populations and escape from specialist herbivores contribute to invasiveness? J Ecol 93:27-37

Thébaud C, Simberloff D (2001) Are plants really larger in their introduced ranges? Am Nat 157:231-236

Thompson JN (1998) Rapid evolution as an ecological process. Trends Ecol Evol 13:329-332

Tilman D (1982) Resource competition and community structure. Princeton University Press, Princeton, New Jersey, USA

Vilà M, Gómez A, Maron JL (2003) Are alien plants more competitive than their native conspecifics? A test using Hypericum perforatum L. Oecologia 137:211-215

Vilà M, Maron JL, Marco L (2005) Evidence for the enemy release hypothesis in Hypericum perforatum. Oecologia 142:474-479

Vitousek PM, D'Antonio CM, Loppe LL, Westbrooks R (1996) Biological invasions as global environmental change. Am Sci $84: 468-478$

Walker NF, Hulme PE, Hoelzel AR (2003) Population genetics of an invasive species, Heracleum mantegazzianum: implications for the role of life history, demographics and independent introductions. Mol Ecol 12:1747-1756

Warwick SI, Thompson BK, Black LD (1987) Genetic variation in Canadian and European populations of the colonizing weed species Apera spica-venti. New Phytol 106:301-317

Weber E, D'Antonio CM (1998) Phenotypic plasticity in hybridizing Carpobrotus ssp. (Aizoaceae) from coastal California and its role in plant invasions. Can J Bot 77:1411-1418

Williamson M (1996) Biological invasions. Chapman and Hall, London

Willis AJ, Blossey B (1999) Benign environments do not explain the increased vigour of non-indigenous plants: a cross-continental transplant experiment. Biocontrol Sci Tech 9:567-577

Willis AJ, Thomas MB, Lawton JH (1999) Is the increased vigour of invasive weeds explained by a trade-off between growth and herbivore resistance? Oecologia 120:632-640

Willis AJ, Memmott J, Forrester RI (2000) Is there evidence for the post-invasion evolution of increased size among invasive plant species? Ecol Lett 3:275-283

Wolfe LM (2002) Why alien invaders succeed: support for the escape-from-enemy hypothesis. Am Nat 160:705-711

Wolfe LM, Elzinga JA, Biere A (2004) Increased susceptibility to enemies following introduction in the invasive plant Silene latifolia. Ecol Lett 7:813-820

Woodburn TL, Sheppard AW (1996) The demography of Carduus nutans as a native and an alien weed. Plant Protect Q 11:236238 